\title{
CELL-MEDIATED IMMUNITY IN EXPERIMENTAL PARAINFLUENZA TYPE 3 VIRUS INFECTION
}

\author{
INDRANI RAMAKRISHNAN AND S.C. AgaRWAL \\ Department of Microbiology, Jawaharlal Institute of Postgraduate Medical Education and \\ Research, Pondicherry-605006, India

\section{Plates XXXIII-XXXV}

PARAINFLUENZA viruses are mainly reported as causing respiratory-tract infections in children. Of the four types, parainfluenza type 4 is the least and type 3 is the most frequently reported. Parainfluenza type 3 (PI-3) is found more often in very young children. The lungs are the main site of infection and local immunity develops early (Smith et al., 1966; Kasel et al., 1969).

Reports on cell-mediated immune responses during experimental respiratory-virus infections are few (Waldman and Ganguly, 1974). Delayed hypersensitivity has been demonstrated after parenteral administration of inactivated respiratory syncytial virus (Forsyth, 1968; Tremonti and Jackson, 1969) and inactivated influenza virus (Feinstone, Beachey and Rytel, 1969). There are some conflicting reports of suppression of cell-mediated immunity (CMI) in respiratory viral infection (Kantzler et al., 1974; Kauffman et al., 1974). Even the reports on the development of delayed hypersensitivity after experimental inoculation of live PI-3 virus are contradictory. Tremonti and Jackson (1969) failed to induce a delayed hypersensitivity response by intranasal inoculation of live PI-3 virus whereas Wetherbee (1973) could induce it. We have produced PI-3 virus infection in the respiratory tract of guinea-pigs and have studied the development of systemic CMI for 70 days, using dermal reactivity, leucocyte-migration inhibition (LMI), macrophage-migration inhibition (MMI), macrophage aggregation (MA) and adoptive spleen-cell transfer as indicators.

\section{MATERIALS AND METHODS}

Media

Hanks's balanced salt solution (HBSS) containing penicillin 100 units $/ \mathrm{ml}$, streptomycin 100 $\mu \mathrm{g} / \mathrm{ml}$ and heparin 5 units $/ \mathrm{ml}$ and Eagle's minimum essential medium with Earle's basic salt solution (MEM) were prepared according to Lennette and Schmidt (1964). MEM also contained glutamine $3 \%$ (w/v), penicillin $100 \mathrm{units} / \mathrm{ml}$ and streptomycin $100 \mu \mathrm{g} / \mathrm{ml}$. Enriched MEM was prepared by the addition of $10 \%(\mathrm{v} / \mathrm{v})$ heat-inactivated bovine serum to MEM. The $p \mathrm{H}$ of the final medium was adjusted to $7 \cdot 2$ with $1.4 \%(\mathrm{w} / \mathrm{v})$ sodium bicarbonate. 


\section{Animals}

Healthy guinea-pigs of both sexes weighing $300-400 \mathrm{~g}$, bred and maintained in our institute animal house, were used. They were given a diet of Bengal gram and vegetables and water ad lib. They were kept in separate cages.

\section{Virus}

Parainfluenza 3 virus was used. Pools of infective virus were prepared in HeLa monolayer cell culture. Cells infected with the virus were harvested after incubation for 3 days. The infected tissue-culture fluid was centrifuged at 2000 r.p.m. for $10 \mathrm{~min}$. and the supernatant fluid was stored at $-60^{\circ} \mathrm{C}$.

\section{Titration of virus}

From each of a series of tenfold dilutions of virus suspension in Eagles maintenance medium, $0.2 \mathrm{ml}$ was inoculated into three sets of HeLa cell-culture tubes. After incubation for 3 days, the tubes were washed twice with $1 \mathrm{ml}$ of MEM; $1 \mathrm{ml}$ of $0.1 \%$ guinea-pig erythrocyte suspension in MEM was added to each tube and the tubes were kept at $4^{\circ} \mathrm{C}$ for $30 \mathrm{~min}$. The cultures were examined microscopically for evidence of haemadsorption. The titre, calculated by the method of Reed and Muench (1938), was $10^{5.5} 50 \%$ tissue-culture infective doses (TCID50)/ml.

\section{Infection of animals}

Virus suspension $(0 \cdot 2 \mathrm{ml})$ was instilled intranasally into 20 guinea-pigs. Groups of three animals were examined for development of CMI after different time intervals. Their sera were also tested for virus-neutralising antibody by haemadsorption inhibition.

\section{Antisera}

Undiluted virus suspension $\left(0.2 \mathrm{ml}\right.$ of $\left.10^{5.5} \mathrm{TCID} 50 / \mathrm{ml}\right)$ was instilled intranasally into four guinea-pigs. The animals were kept in isolation and bled by cardiac puncture after 21 days. Sera were stored at $-20^{\circ} \mathrm{C}$. The pooled sera had a virus neutralising antibody titre of 1024 .

\section{Measurement of cell-mediated immunity}

Antigen. Dilutions of virus containing $10^{2}$ or $10^{3} \mathrm{TCID} 50 / \mathrm{ml}$ were used for eliciting dermal reactivity, LMI, MMI and MA. The antigen was inactivated by heating in a waterbath at $60^{\circ} \mathrm{C}$ for $1 \mathrm{~h}$. To ensure that there was no live virus in the preparation, $0.2 \mathrm{ml}$ was inoculated into HeLa cell monolayer culture tubes and tested for haemadsorption of guinea-pig erythrocytes after incubation at $37^{\circ} \mathrm{C}$ for 3 days. They did not show any haemadsorption.

Delayed skin hypersensitivity. From each of the two antigen preparations, $\left(10^{2}\right.$ and $10^{3}$ TCID $50 / \mathrm{ml}$ ), $0.1 \mathrm{ml}$ was injected intradermally into different spots in an area of shaved abdominal skin of test animals; 24 and $48 \mathrm{~h}$ later, both sites of inoculation were examined for induration and erythema.

Macrophage migration-inhibition test. The method of David et al. (1964) as described by Agarwal and Sundararaj $(1976,1977)$ was used. The peritoneal macrophages were collected from virus-infected guinea-pigs $48 \mathrm{~h}$ after the intraperitoneal injection of $15 \mathrm{ml}$ of $3 \%(\mathrm{v} / \mathrm{v})$ peptone water. They were harvested in $150-200 \mathrm{ml}$ of cold HBSS containing heparin 5 units $/ \mathrm{ml}$. Any erythrocytes in the macrophage suspension were lysed by keeping the centrifuged macrophage cell pellet in $5 \mathrm{ml}$ of $0.83 \%(\mathrm{w} / \mathrm{v})$ ammonium chloride solution. Separate plastic chambers containing macrophages in microcapillaries were filled with enriched MEM $(3 \mathrm{ml})$ and contained $0.1 \mathrm{ml}$ of either $10^{2}$ or $10^{3} \mathrm{TCID} 50$ antigen $/ \mathrm{ml}$ or no antigen. The area of macrophage migration 
in control and test chambers was recorded with a camera lucida. An average of the migrations from five capillaries was taken and the percentage of migration inhibition was calculated from the formula:

$$
\frac{\text { area of control migration - area of test migration }}{\text { area of control migration }} \times 100 .
$$

Leucocyte migration-inhibition test. This was done by the method of David et al. (1964). Samples of blood $(10 \mathrm{ml})$ were collected in tubes containing $0.25 \mathrm{ml}$ of heparin ( 250 units) and allowed to stand for $1 \mathrm{~h}$ for the erythrocytes to settle. The plasma was collected and centrifuged at 1000 r.p.m. for $10 \mathrm{~min}$. To the cell pellet, $5 \mathrm{ml}$ of $0.83 \%(\mathrm{w} / \mathrm{v}) \mathrm{NH}_{4} \mathrm{Cl}$ was added and the suspension was allowed to stand for $5 \mathrm{~min}$. After the erythrocytes had lysed, the leucocytes were collected by centrifugation at 1500 r.p.m. for $2 \mathrm{~min}$. The cells were then washed thrice with HBSS and suspended in enriched MEM containing antibiotics, and adjusted to a concentration of $2-3 \times 10^{6} \mathrm{cells} / \mathrm{ml}$. The viability of the cells was tested by trypan-blue exclusion. The rest of the procedure was the same as for the MMI test and the area of migration was calculated after incubation of the chambers at $37^{\circ} \mathrm{C}$ for $24 \mathrm{~h}$.

Macrophage-aggregation test. This test was performed as described by Lolekha, Dray and Gotoff (1970). Two ml of enriched MEM containing $2 \times 10^{6}$ peritoneal-exudate cells (PEC) were cultured in siliconised conical tubes $(15 \times 150 \mathrm{~mm})$ in the presence of $10^{3}$ TCID50 of virus antigen. Antigen was not added to the control tubes. All the tubes were incubated at $37^{\circ} \mathrm{C}$ in $5 \% \mathrm{CO}_{2}$ for $24 \mathrm{~h}$. After incubation the cells were suspended by gentle mixing. One drop of cell suspension was placed on a slide and observed by light microscopy $(\times 100)$. The test was done in duplicate and the results were graded from + to ++++ according to Lolekha et al. (1970) by counting the number of cells forming a clump $(+=5-9$ cells, $++=10-15,+++=16-25$, $++++=$ clumping of many cells which settled below the supernatant fluid.

\section{Spleen-cell transfer}

This was done as described by Sundararaj and Agarwal (1977). Guinea-pigs experimentally infected with virus were killed 60 and 70 days after infection and CMI was measured. The spleens, removed and rinsed thrice with MEM containing penicillin $100 \mathrm{units} / \mathrm{ml}$ and streptomycin $100 \mu \mathrm{g} / \mathrm{ml}$, were snipped into small pieces. These pieces were forced through a 40 -mesh stainless-steel sieve. The spleen cells were suspended in MEM and their viability was checked by trypan-blue exclusion. More than $95 \%$ of the cells were viable. The cells were counted in a Neubauer chamber and the suspension was adjusted to $10^{8}-10^{9}$ cells $/ \mathrm{ml}$. The suspension $(0 \cdot 5$ $\mathrm{ml}$ ) was injected intracardially into two normal guinea-pigs which were killed on the 3rd day. LMI, MMI and MA were measured. A piece of spleen removed from an infected guinea-pig was ground well, suspended and centrifuged. The supernate was inoculated into HeLa cell monolayer cultures. After 4 days, viable virus in the cells was sought by haemadsorption and none was found.

\section{Virus-neutralising antibody in serum}

Sera were held at $56^{\circ} \mathrm{C}$ for $30 \mathrm{~min}$. Twofold dilutions of the test serum were prepared in MEM. An equal volume $(0.1 \mathrm{ml})$ of virus was added to each serum dilution and the serum-virus mixtures were incubated at room temperature for $1 \mathrm{~h}$.

After incubation, $\mathbf{0} \cdot 2 \mathrm{ml}$ of each serum-virus mixture was inoculated into three sets of HeLa cell cultures. After incubation at $35^{\circ} \mathrm{C}$ for 3 days the test was read, haemadsorption inhibition indicating the end point as follows. The cultures were washed twice with MEM then $1 \mathrm{ml}$ of a $0.1 \%(\mathrm{v} / \mathrm{v})$ suspension of guinea-pig erythrocytes was added to each tube. After incubation at $4^{\circ} \mathrm{C}$ for $30 \mathrm{~min}$., the tubes were examined microscopically for haemadsorption. Complete inhibition of haemadsorption was taken to indicate neutralisation. The serum end point was estimated by the method of Reed and Muench (1938).

Histological examination of tissue from both lungs and from the trachea was made on all 
experimentally infected guinea-pigs, which were killed after different time intervals. The tissues were fixed in $10 \%$ formol saline. Sections were cut at $4 \mu \mathrm{m}$ and stained with haematoxylin and eosin.

\section{RESULTS}

The concentrations of virus antigen that did not, by themselves, increase the LMI or MMI when added to migration chambers containing macrophages or leucocytes from non-immune guinea-pigs were determined. These antigen concentrations of virus suspension could safely be used for inducing CMI in macrophages or leucocytes from PI-3-infected guinea-pigs. The results obtained in virus-infected guinea-pigs after various time intervals and by different indicators of CMI were as follows.

\section{Dermal reactivity}

At no time during the course of 70 days of experimental virus infection could dermal reactivity be elicited by intradermal injection of $0.2 \mathrm{ml}$ of $10^{2.0}$ or $10^{3.0} \mathrm{TCID} 50$ antigen $/ \mathrm{ml}$. Erythema or induration could not be found $24-48 \mathrm{~h}$ after injection.

\section{Macrophage-migration inhibition (table 1)}

In the first group, 10 days after infection, one guinea-pig (no. 5) showed increase in MMI at both the concentrations of antigen. Twenty days after infection, all the three guinea-pigs (nos. 6, 9 and 10) showed good inhibition after the injection of the $10^{3}$ TCID50 preparation. But after infection with the $10^{2}$ TCID50 preparation, only two guinea-pigs (nos. 6 and 10) showed increased MMI. Thirty days after infection, all the three guinea-pigs (nos. 3, 11 and 12) showed increased MMI at both concentrations of antigen. Similar results were obtained in guinea-pigs examined 40, 50,60 and 70 days after infection.

\section{Leucocyte migration inhibition (table I)}

In the first group of three guinea-pigs, some inhibition was induced in the leucocytes from two (nos. 7 and 8) 10 days after infection, by the addition of the $10^{3}$ TCID50 antigen preparation to the migration-chamber fluid. However, with the $10^{2}$ TCID50 antigen preparation in the migration-chamber fluid, leucocytes from none of the guinea-pigs showed inhibition. Twenty days after infection, the results were generally similar except that the increase in LMI was more pronounced and the leucocytes from guinea-pig no. 10 showed increased LMI with the $10^{2}$ TCID50 antigen preparation. Thirty days after infection, the leucocytes from all the guinea-pigs (nos. 3,11 and 12) showed considerable increase in LMI with the $10^{3}$ TCID50 preparation in the migration-chamber fluid. After addition of the $10^{2}$ TCID50 preparation, however, two guineapigs (nos. 3 and 12) showed increased LMI. Forty days after infection, all the 
three guinea-pigs (nos. 4, 13 and 14) showed increased LMI after addition of antigen at both concentrations. At 50,60 and 70 days after infection, increased LMI was induced by both these concentrations of the antigen in all the guinea-pigs studied (nos. 15, 17 and 18).

\section{Macrophage aggregation (table I)}

Macrophages were seen to aggregate in the presence of antigen preparation $10^{3} \mathrm{TCID} 50 / \mathrm{ml}$ in all the guinea-pigs 20 days and more after infection. In control animals, there was no aggregation of macrophages.

\section{Virus-neutralising antibody (table I)}

The virus-neutralising antibody was present 10 days after infection (titre of 32,64 and 64 in guinea-pigs nos. 5, 7 and 8, respectively). Titres increased to 512 and 1024 and remained at this high level even up to 60 and 70 days after infection.

TABLE I

Development of cell-mediated immunity in guinea-pigs after experimental infection with parainfluenza 3 virus

\begin{tabular}{|c|c|c|c|c|c|c|c|}
\hline \multirow{2}{*}{$\begin{array}{c}\text { Guinea-pig } \\
\text { no. }\end{array}$} & \multirow{2}{*}{$\begin{array}{l}\text { Days after } \\
\text { infection }\end{array}$} & \multicolumn{2}{|c|}{$\begin{array}{l}\text { MMI (percentage)* } \\
\text { by antigen } \\
\text { preparation }\end{array}$} & \multicolumn{2}{|c|}{$\begin{array}{l}\text { LMI (percentage)* } \\
\text { by antigen } \\
\text { preparation }\end{array}$} & \multirow{2}{*}{$\begin{array}{l}\text { MA by } \\
\text { antigen } 10^{3} \\
\text { TCID } 50\end{array}$} & \multirow{2}{*}{$\begin{array}{l}\text { Titre of } \\
\text { virus-neutralising } \\
\text { antibody }\end{array}$} \\
\hline & & $\begin{array}{c}10^{3} \\
\text { TCID } 50 / \mathrm{ml}\end{array}$ & $\begin{array}{c}10^{2} \\
\mathrm{CID} 50 / \mathrm{ml}\end{array}$ & $\begin{array}{c}10^{3} \\
\mathrm{CID} / 10\end{array}$ & $\begin{array}{c}10^{2} \\
\mathrm{CID} / 50 \mathrm{ml}\end{array}$ & & \\
\hline $\begin{array}{l}5 \\
7 \\
8\end{array}$ & $\begin{array}{l}10 \\
10 \\
10\end{array}$ & $\begin{array}{l}30 \cdot 1 \\
24 \cdot 5 \\
12 \cdot 0\end{array}$ & $\begin{array}{r}28.9 \\
24.1 \\
1.6\end{array}$ & $\begin{array}{r}6 \cdot 6 \\
42 \cdot 2 \\
52 \cdot 0\end{array}$ & $\begin{array}{r}3 \cdot 6 \\
22 \cdot 3 \\
26 \cdot 3\end{array}$ & $\begin{array}{c}\text { Not done } \\
+ \\
+\end{array}$ & $\begin{array}{l}32 \\
64 \\
64\end{array}$ \\
\hline $\begin{array}{r}6 \\
9 \\
10\end{array}$ & $\begin{array}{l}20 \\
20 \\
20\end{array}$ & $\begin{array}{l}37 \cdot 6 \\
56 \cdot 2 \\
75 \cdot 2\end{array}$ & $\begin{array}{l}31 \cdot 6 \\
12 \cdot 5 \\
44 \cdot 2\end{array}$ & $\begin{array}{l}16 \cdot 4 \\
36 \cdot 1 \\
65 \cdot 9\end{array}$ & $\begin{array}{l}12 \cdot 0 \\
16 \cdot 6 \\
51 \cdot 6\end{array}$ & $\begin{array}{c}\text { Not done } \\
++ \\
++\end{array}$ & $\begin{array}{l}128 \\
128 \\
512\end{array}$ \\
\hline $\begin{array}{r}3 \\
11 \\
12\end{array}$ & $\begin{array}{l}30 \\
30 \\
30\end{array}$ & $\begin{array}{l}77 \cdot 3 \\
52 \cdot 7 \\
65 \cdot 7\end{array}$ & $\begin{array}{l}70 \cdot 0 \\
44 \cdot 3 \\
46 \cdot 3\end{array}$ & $\begin{array}{l}81 \cdot 6 \\
31 \cdot 3 \\
57 \cdot 8\end{array}$ & $\begin{array}{r}57.5 \\
2.5 \\
47.7\end{array}$ & $\begin{array}{l}\text { Not done } \\
+++ \\
+++\end{array}$ & $\begin{array}{r}512 \\
512 \\
1024\end{array}$ \\
\hline $\begin{array}{r}4 \\
13 \\
14\end{array}$ & $\begin{array}{l}40 \\
40 \\
40\end{array}$ & $\begin{array}{l}64 \cdot 7 \\
37 \cdot 7 \\
40 \cdot 5\end{array}$ & $\begin{array}{l}40 \cdot 9 \\
36 \cdot 7 \\
20 \cdot 6\end{array}$ & $\begin{array}{l}33 \cdot 2 \\
50 \cdot 7 \\
54 \cdot 2\end{array}$ & $\begin{array}{l}41 \cdot 3 \\
28 \cdot 8 \\
32 \cdot 9\end{array}$ & $\begin{array}{l}+++ \\
+++ \\
+++\end{array}$ & $\begin{array}{r}1024 \\
1024 \\
512\end{array}$ \\
\hline $\begin{array}{l}15 \\
16\end{array}$ & $\begin{array}{c}50 \\
\text { Died }\end{array}$ & $45 \cdot 2$ & $35 \cdot 1$ & $40 \cdot 3$ & $40 \cdot 1$ & $\begin{array}{c}++ \\
\ldots\end{array}$ & 1024 \\
\hline 17 & 60 & $51 \cdot 3$ & $46 \cdot 2$ & $50 \cdot 2$ & $44 \cdot 1$ & +++ & 1024 \\
\hline 18 & 70 & 40.5 & 37.3 & $56 \cdot 3$ & $50 \cdot 7$ & ++ & 512 \\
\hline $\begin{array}{l}1 \\
2\end{array}$ & $\begin{array}{l}\text { Uninfected } \\
\text { control } \\
\text { Uninfected }\end{array}$ & $3 \cdot 8$ & $2 \cdot 1$ & $3 \cdot 1$ & 1.9 & - & 8 \\
\hline & control & 5.4 & $3 \cdot 2$ & $5 \cdot 3$ & $2 \cdot 8$ & - & 8 \\
\hline
\end{tabular}

TCID50 $=50 \%$ tissue-culture infective dose.

MMI = macrophage-migration inhibition; LMI = leucocyte-migration inhibition;

$\mathrm{MA}=$ macrophage aggregation.

$+=$ Aggregation of 5-9 cells; $++=$ aggregation of $10-15$ cells; $+++=$ aggregation of $16-25$ cells;

$-=$ no aggregation.

* See Materials and methods for method of calculation. 


\section{Adoptive transfer of cell-mediated immunity (table II)}

Spleen-cell transfers were made from two guinea-pigs (nos. 17 and 18) 60 and 70 days after infection into each of two normal seronegative guinea-pigs. All the immune recipient guinea-pigs into which the adoptive transfers were made showed good inhibition in the LMI and MMI tests. Dermal reactivity was, however, not present in these recipient animals when they were tested by intradermal injection of both the dilutions of antigen.

TABLE II

Adoptive transfer of cell-mediated immunity to guinea-pigs by immune spleen cells of guinea-pigs infected with parainfluenza 3 virus

\begin{tabular}{|c|c|c|c|c|c|}
\hline \multirow{2}{*}{$\begin{array}{c}\text { Guinea-pig } \\
\text { no. }\end{array}$} & \multirow{2}{*}{$\begin{array}{l}\text { Days after } \\
\text { infection }\end{array}$} & \multicolumn{2}{|c|}{$\begin{array}{l}\text { MMI (percentage)* by } \\
\text { antigen preparation }\end{array}$} & \multicolumn{2}{|c|}{$\begin{array}{l}\text { LMI (percentage)* by } \\
\text { antigen preparation }\end{array}$} \\
\hline & & $10^{3} \mathrm{TCID} 50 / \mathrm{ml}$ & $10^{2} \mathrm{TCID} / \mathrm{ml}$ & $10^{3} \mathrm{TCID} 50 / \mathrm{ml}$ & $10^{2} \mathrm{TCID} 50 / \mathrm{ml}$ \\
\hline $\begin{array}{l}17 \\
17 / 1 \\
17 / 2\end{array}$ & $\begin{array}{l}60 \\
60 \\
60\end{array}$ & $\begin{array}{l}51 \cdot 3 \\
63 \cdot 3 \\
62 \cdot 6\end{array}$ & $\begin{array}{l}46 \cdot 2 \\
46 \cdot 4 \\
50 \cdot 0\end{array}$ & $\begin{array}{l}50 \cdot 2 \\
64 \cdot 1 \\
59 \cdot 3\end{array}$ & $\begin{array}{l}44 \cdot 1 \\
42 \cdot 2 \\
47 \cdot 2\end{array}$ \\
\hline $\begin{array}{l}18 \\
18 / 1 \\
18 / 2\end{array}$ & $\begin{array}{l}70 \\
70 \\
70\end{array}$ & $\begin{array}{l}40 \cdot 5 \\
53 \cdot 1 \\
43 \cdot 4\end{array}$ & $\begin{array}{l}37 \cdot 3 \\
46 \cdot 9 \\
41 \cdot 4\end{array}$ & $\begin{array}{l}56 \cdot 3 \\
61 \cdot 6 \\
78 \cdot 1\end{array}$ & $\begin{array}{l}30 \cdot 7 \\
55 \cdot 0 \\
58 \cdot 4\end{array}$ \\
\hline
\end{tabular}

Footnotes as in table I.

\section{Histopathology}

Ten days after infection, the lungs showed severe congestion and some areas of interstitial pneumonitis. The alveolar capillaries were dilated and ruptured in places. There were areas in which the alveolar spaces were completely obliterated and the septa were thickened, hypercellular and infiltrated with chronic inflammatory cells. In the trachea, the capillaries of the submucosa were dilated and there was a diffuse infiltration of mononuclear cells. Twenty days after infection the septal thickening and obliteration of the alveolar spaces in the lungs had increased. The capillaries were dilated and ruptured in many places (figs. 1 and 2). The histopathological appearance of the trachea at this time was similar to that at 10 days after infection, except that the inflammatory mononuclear-cell response was more severe (fig. 3). Thirty days after infection, the histopathological changes in the lungs and trachea had progressed further. Forty days after infection the lungs showed marked congestion of the alveolar septa, dilatation and rupture of capillaries and a heavy mononuclear cellular response. Focal areas of intraalveolar haemorrhages were also present. The trachea showed a diffuse infiltration with chronic inflammatory cells and dilatation of capillaries (figs. 4 and 5). The general appearances were those of interstitial pneumonitis. Similar histopathological features were found in the lungs and trachea of guinea-pigs 50 days after infection. They were less marked 60 and 70 days after infection. 


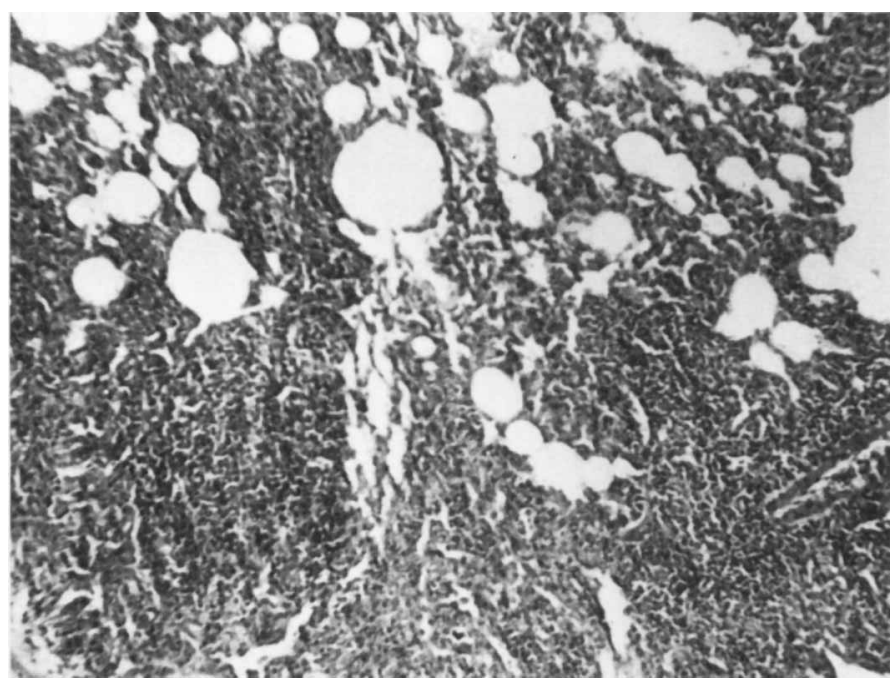

FIG. 1. - Lung, 20 days after infection. Shows hypercellularity and heavy mononuclear-cell infiltration of alveolar septa and obliteration of air spaces. Haematoxylin-eosin $(\mathrm{HE}) . \times 112$.

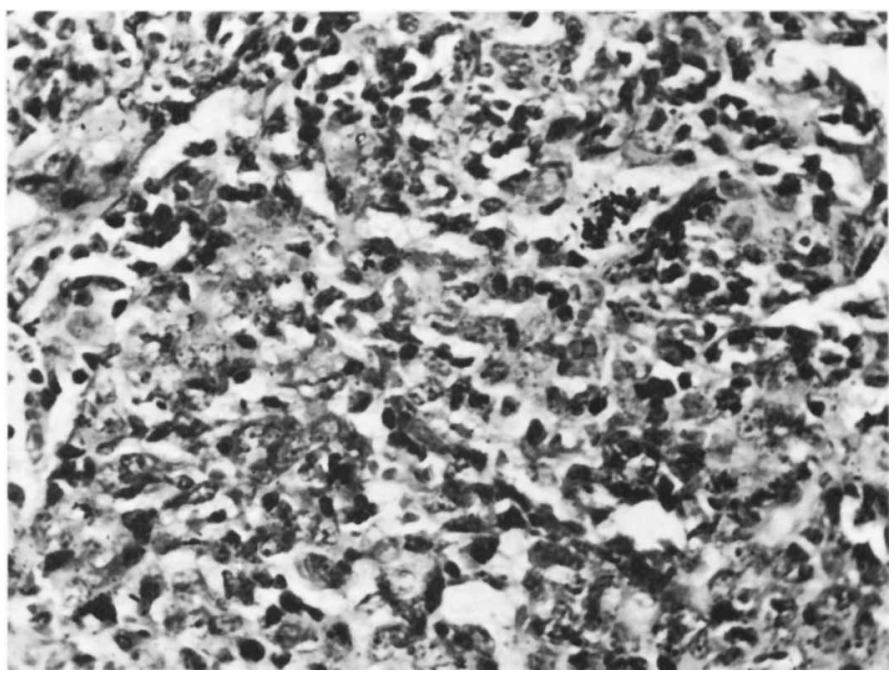

FIG. 2.--Lung, 20 days after infection. Note the marked obliteration of alveolar spaces and mononuclearcell infiltration. HE. $\times 450$. 


\section{CELl-MEdiated IMMUNity TO PARAINFLUENZA VIRUS}

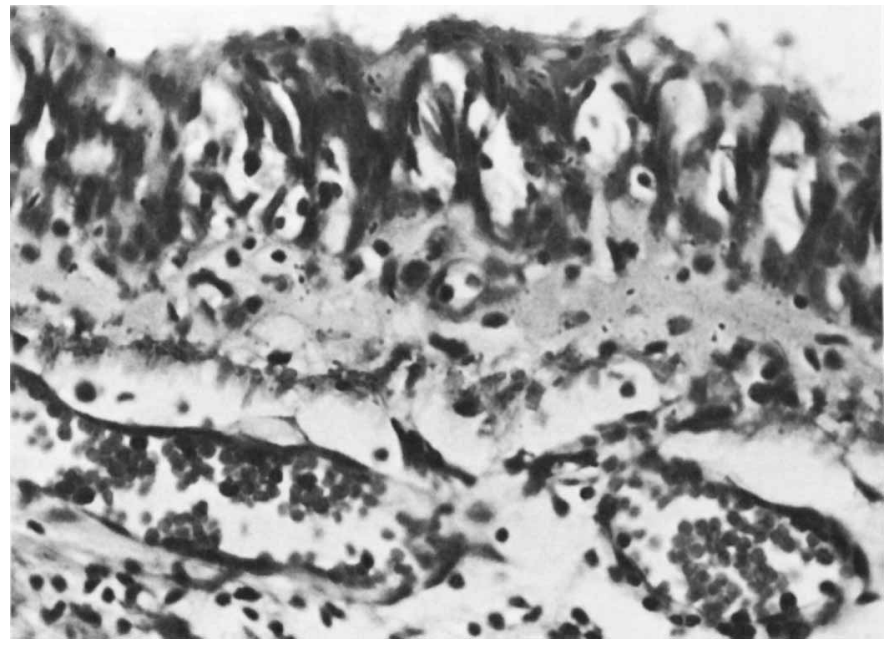

FIG. 3 -Trachea, 20 days after infection. Note the focal aggregate of chronic inflammatory cells. HE. $\times 450$.

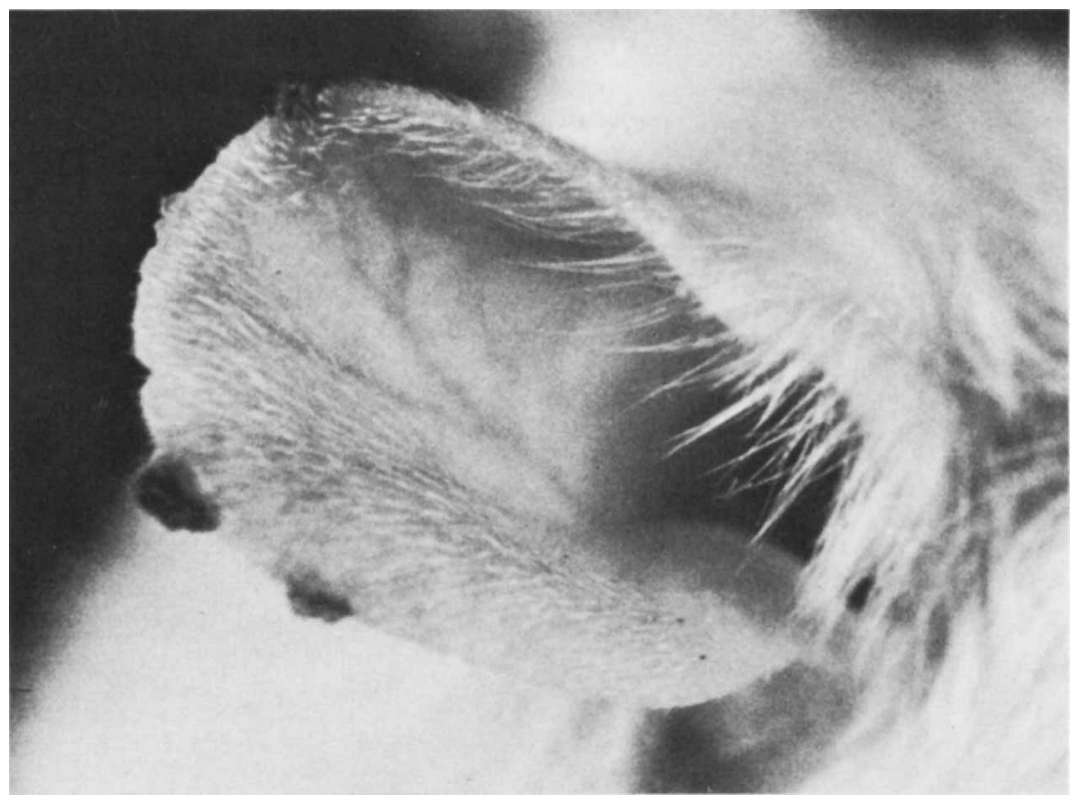

FIG. 4.-Lung, 40 days after infection. Shows marked dilatation of capillaries, rupture and haemorrhages and a diffuse infiltration of interalveolar septa with mononuclear cells. Note the obliteration of air spaces. HE. $\times 600$. 


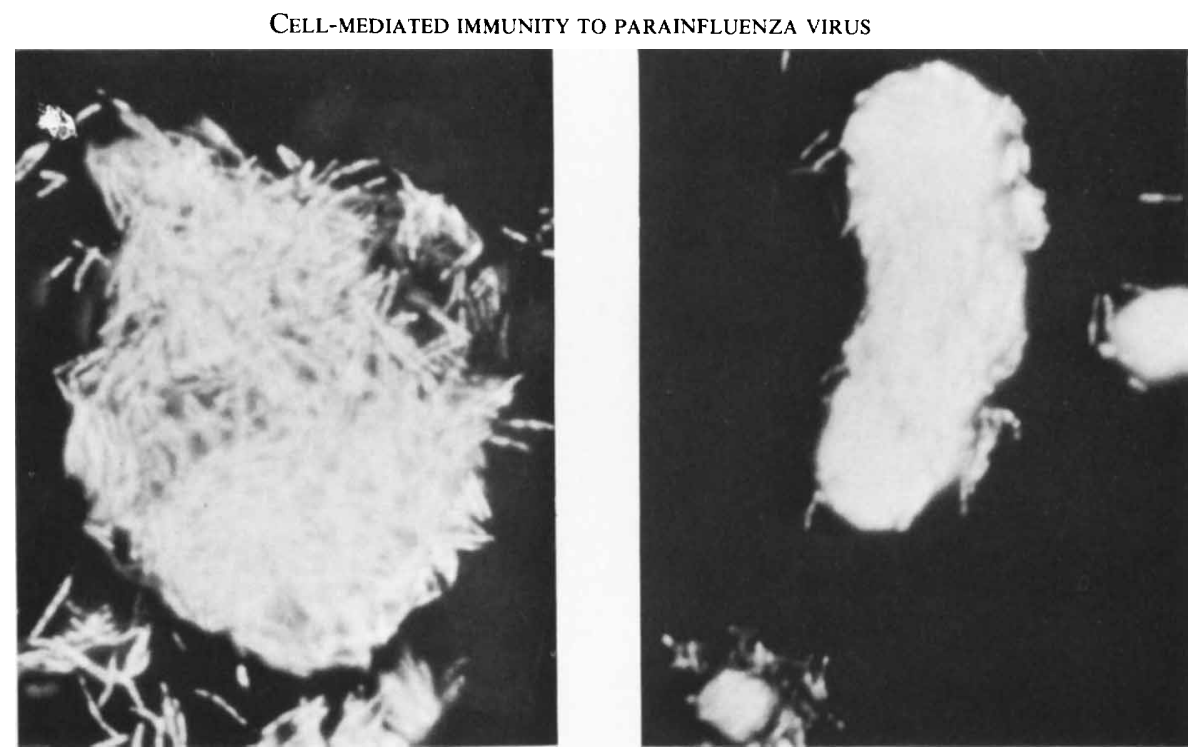

FIG. 5.-Trachea, 40 days after infection. Shows a diffuse infiltration with chronic inflammatory cells and dilatation of blood capillaries in the submucosa. HE. $\times 600$. 


\section{DisCUSSION}

Our results showed that experimental respiratory infection with PI-3 virus in the guinea-pig produced a systemic cell-mediated immunity which persisted for at least 70 days after infection. It is interesting that dermal reactivity was not found at any time during the course of respiratory-tract infection even though cellular immunity was present, as indicated by LMI, MMI, MA and adoptive cell-transfer experiments. Such a dissociation of dermal reactivity from other manifestations of CMI has been reported by us (Sundararaj and Agarwal, 1977) and others (Osebold, Pearson and Medin, 1974).

The development of CMI, as shown by an increase in migration-inhibition factors, had begun by the 10th day after infection although, by then, evidence of CMI was found in only one guinea-pig, and in that it was elicited only by antigen at a concentration of $10^{3 \cdot 0}$ TCID $50 / \mathrm{ml}$.

The local infection was established in the lung tissue by the 10th day as shown by the presence of areas of interstitial pneumonitis. Good CMI appeared 20 days after intranasal instillation of the virus and persisted for at least 70 days. This was shown by the increase in the LMI and MMI in animals killed from the 30th to the 70th day after infection. The CMI could be adoptively transferred to non-immune guinea-pigs by immune spleen-cell transfer even in the later stages of experimental infection, i.e., 60 and 70 days after infection. This was amply shown by the increased LMI and MMI in the recipient guinea-pigs. The recipient animals, like the donors, did not show any dermal reactivity.

The development of CMI could be correlated with the presence of histopathological changes in lung and tracheal tissue. Ten days after infection, when the virus had produced focal areas of interstitial pneumonitis, the CMI had just started appearing. The gross pathological lesions were seen up to 70 days after infection. Forty days after infection the lung tissue showed a slight clearing; the alveolar septa were less thickened and some alveolar spaces could be made out. However, there was marked dilatation and rupture of capillaries. Considerable interstitial pneumonitis was present up to the 50th day and it was less marked by the 70 th day after infection. The inflammatory cell response in the lower part of the trachea had diminished by the 40th day. During this period the systemic CMI was certainly increased and was counteracting the local respiratory-tract infection. We feel that systemic cellular immunity might have an important role in addition to the local immunity in determining the course of the parainfluenza type 3 respiratory-tract infection. Humoral antibodies also appeared and progressively increased during the course of infection; these may be supplementing cell-mediated immunity in the localisation and clearing of viral pneumonitis.

\section{SUMmary}

Local respiratory-tract infection was produced experimentally in guineapigs by intranasal instillation of a suspension of parainfluenza virus type 3 . 
Histologically, interstitial pneumonitis developed within 10 days and persisted for at least 70 days.

Cell-mediated immunity was measured at intervals for 70 days after infection. Dermal reactivity could not be elicited. Leucocyte-migration inhibition and macrophage-migration inhibition were increased. Macrophage aggregation was present. Increased cell-mediated immunity could be transferred from infected donor animals to normal recipient animals by adoptive spleen-cell transfer even 60 and 70 days after infection.

\section{REFERENCES}

Agarwal, S. C. and SundararaJ, T. (1976) Cell-mediated immunity to Vibrio cholerae with ribonucleic acid-protein fraction of $V$. cholerae $\mathrm{L}$-form lysate. Infect. Immun., 14, 363.

Agarwal, S. C. AND SundararaJ, T. (1977) Cell-mediated immunity after oral immunization with ribonucleic acid protein fractions of Vibrio cholerae L-form lysates. Infect. Immun., $16,527$.

David, J. R., Al-Askari, S., Lawrence, H. S. and Thomas, L. (1964) Delayed hypersensitivity in vitro. 1. The specificity of inhibition of cell migration by antigens. J. Immun., 93, 264.

Feinstone, S. M., Beachey, E. H. and Rytel, M. W. (1969) Induction of delayed hypersensitivity to influenza and mumps viruses in mice. J. Immun., 103, 844.

FORSYTH, B. R. (1968) Development of delayed dermal hypersensitivity in guinea-pigs immunized with inactivated respiratory syncytial virus vaccines. Proc. Soc. exp. Biol. Med., $129,777$.

Kantzler, G. B., Lauteria, S. F., Cusamano, C. L., Lee, J. D., Ganguly, R. and Waldman, R. H. (1974) Immunosuppression during influenza virus infection. Infect. Immun., 10, 996.

Kasel, J. A., Hume, E. B., Fulk, R. V., Togo, Y., Huber, M. And Hornick, R. B. (1969) Antibody responses in nasal secretions and serum of elderly persons following local or parenteral administration of inactivated influenza virus vaccine. J. Immun., 102, 555.

Kauffman, C. A., Linnemann, C. C., JR., Tan, J. S., Schiff, G. M. and Phair, J. P. (1974) Cell-mediated immunity in humans during viral infection: Dermal hypersensitivity and in vitro lymphocyte proliferation during mild viral respiratory infections. Infect. Immun., 10, 757.

Kaufmann, C. A., Linnemann, C. C., JR., Schiff, G. M. And Phair, J. P. (1976) Effect of viral and bacterial pneumonias on-cell mediated immunity in humans. Infect. Immun., 13, 78.

LenNeTte, E. H. AND SCHMidT, N. J. (1964) Diagnostic procedures for viral and rickettsial diseases, 3rd ed. American Public Health Association: New York.

Lolekha, S., Dray, S. AND GotofF, S. P. (1970) Macrophage aggregation in vitro: a correlate of delayed hypersensitivity. J. Immun., 104, 296.

Osebold, J. W., Pearson, L. D. ANd Medin, N. I. (1974) Relationship of antimicrobial cellular immunity to delayed hypersensitivity in listeriosis. Infect. Immun., 9, 354.

REED, L. J. AND MUENCH, H. (1938) A simple method of estimating fifty per cent endpoints. Am. J. Hyg., 27, 493.

Smith, C. B., Purcell, R. H., Bellanti, J. A. and Chanock, R. M. (1966) Protective effect of antibody to parainfluenza type 1 virus. New Engl. J. Med., 275, 1145.

Smith, C. B., Bellanti, J. A. AND Chanock, R. M. (1967) Immunoglobulins in serum and nasal secretions following infection with type 1 parainfluenza virus and injection of inactivated vaccines. J. Immun., 99, 133.

SundararaJ, T. AND Agarwal, S. C. (1977) Cell-mediated immunity in experimental Nocardia asteroides infection. Infect. Immun., 15, 370 .

TREMONTI, L. P. AND JACKSON, G. G. (1969) Study of delayed hypersensitivity to myxoviruses induced by vaccines. Appl. Microbiol., 17, 577.

WALDMAN, R. H. AND GANGULY, R. (1974) Immunity to infection on secretory surfaces. $J$. infect. Dis., 130, 419.

WETHERBEE, R. E. (1973) Induction of systemic delayed hypersensitivity during experimental viral infection of the respiratory tract with a myxovirus or a paramyxovirus. J. Immun., $111,157$. 